suthor of the former work speaks of them as composed principelly of phosphate of lime. Professor Syme says, "Their composition is phosphate of lime, agglutinated by a small quantity of animal matter." Rokitansky says, "They are composed of phosphate and carbonate of lime, held together by animal matter." (Jones and Sieveking's Pathological Anatomy. p. 578.)

If we but glance at the anatomical arrangement of the submaxillary region, the necessity for incision, and, at the same time, the extreme caution required in making it, will be apparent. Covering in the submaxillary gland, we have not only the ordinary integuments, but the platysma myoides, and beneath this a very strong dense fascia, which completely envelopes, or as it were forms a nest, for the gland. The tension of these structures, tcgether with the "strangulation" of the inflamed gland, from their unyielding nature, especially that of the fascial envelope of the gland, no doubt occasioned the intense irritation. The vessels of this part are large, tortuous, and irregular; the facial vein, though of very considerable size, and comparatively superficial, is pretty constant as far as regards its position; but the artery of the same name, taking an exceedingly tortuous course through the substance of the submaxillary gland, frequently gives either a not insignificant submental branch, or the sublingual itself. Now, although, in an operating theatre, under a skylight, these would be but slight impediments to an operation ; on a low truckle bed, in an almost dark room, it would amount to an awkward contretemps to wound cither of the ressels above named, especially taking into account the infiltrated condition of the surrounding tissues-a condition not favourable to retraction of the ends of the divided trunk.

Suppuration of the submaxillary gland, I believe, is extremely rare; I have never met with but one other case, and that was in a girl of about 20 years of age. Nothing peculiar was to be found to explain the occurrence of the inflammatory attack in this case. It is common enough to see enlargement of the submaxillary lymphatic glands in scrofulous children; but, from the circumstance of these glands not being bound down by what is called the deep cervical fascia, no extraordinary inconvenience or irritation results ; and, when they suppurate, they may be opened without risk. The above case has been detailed as being probably unique, and also as affording an example of the severity of the constitutional disturbance in subaponeurotic collections of matter.

\section{Grianal Communitations.}

\section{CASE OF POISONING BY STRYCHNINE.}

By THOMAS NUNNELEY, F.R.C.S., Lecturer on Surgery in the Scliool of Medicine, Leeds.

THe following case, which came under my notice last May, I have for some time past intended to forward for publication in the Jodrasu. The interest which it possesses in itself is now incrcased by the notorious case at Rugeley, and therefore, I now send it without further delay. The curious circumstances under which the poison was takenthe post mortem appearances, differing, as they did, in the absence of muscular rigidity, from what is commonly observed in animals killed with strychnine-and the detection of the poison in the contents of the stomach at a considerably later period than, if the newspaper reports are correct (which I doubt), might be supposed probable according to the evidence of Dr. Taylor in the case of Cook, are all worthy of attention.

Cage. On the afternoon of May 19th, 1855, I received the coroner's order to examine the body of Ellen Water. house, a stranger in Leeds, who had died under suspicious circumstances during the night. A short time before her death she sajd she had taken poison, but gave no clue as to it nature, or how she had taken it. $\Delta$ fter her death, in examining her dress pockets, two empty small paper packets were found, the outer and inner bags of one packet of "Battle's Vermin Killer", according to the printed label upon them; they were folded up, the inner within the outer. There was also found a box of pills and a bottle of medicine, out of which one dose had been taken. These, it was ascertained, had been obtained for her a day or two before from some one at Huddersfield for a renereal complaint, and were of a simple character.

The young woman presented herself at a public house in Leeds at a quarter before twelve o'clock on Friday night, May 18th, where she asked for a bed, stating that she had just come from Huddersfield by the last train, and was disappointed in not finding the house of her uncle. There is no doubt of the truth of the statement, for she was seen at her own home, two miles from Huddersfield, between eight and nine o'clock the same evening, quite cheerful; the train leaves Huddersfield at a quarter past ten, and arrives at Leeds at a quarter past eleren o'clock. She had an uncle who had lately removed from the neighbourhood of the public house, which is some little distance from the station. The landlady refused her a bed, when a poor man, who lived near, and was upon the point of going home, thinking it was a pity that a good looking and apparently respectable young woman should walk about the streets all night, from friendly feeling took her home to sleep with his children. She did not sit down in the public house, nor did she take anything. She appears to have sat in the cottage talking to the man and his wife till halfpast twelre o'clock, and then retired up stairs, and got into a small bed with two children, the woman going into her own bed. The chamber was a small one. She did not eat or drink before going to bed, when she appeared to fall asleep; at least Mirs. Sheard, who says she lay awake for an hour, thought so, and was quite certain the girl did not get out of bed or move much about, and that there was no water or other fluid in the room, nor any ressel to drink out of. The man retired to bed after the woman thought her asleep. At a quarter to two o'clock Mrs. Sheard was awoke by the moaning of the girl, who was then, or immediately after, severely convulsed; the convulsions continued at frequent intervals for an hour. For another hour she was comparatively free from convulsion, and talked calmly and distinctly about her parents, and the conduct of her lover, and her having done something wrong, but refused to say what. During this time she drank freely of cold water, which was fetched from the room below, when a violent convulsion came on, in which she died. From the evidence of Mrs. Sheard it was very difficult to determine the exact form of the convulsions, as she did not at the time appear to consider the throwing about of the arms as convulsions; but from what I could make out, I have no doubt the lower extremities were principally rigidly extended, while the upper were strongly conrulsed. It was owing to a more violent convulsion not very long before the girl's death that Mrs. Sheard became seriously alarmed, and sent her husband to seek a medical man; during his absence death occurred, the girl continuing sensible until the last minute or two.

Subjoined is a verbatim report of the evidence alluded to :-

"Abraham Waterhouse, the father of the deceased, deposed that she was twenty years of age, and in service at Huddersfield; that she was not in very good health, but her parents did not know what ailed her: that she was at his house, about two miles from Huddersfield, so late as eight o'clock on Friday night, May 18th, where she stayed about an hour, and was as cheerful as he had ever known her. She stated her reason for calling was to borrow a carpet bag, as she proposed going to Liverpool the next. morning.

"Thomas Sheard, Wellington Place, Wellington Lane, cloth dresser. I was at the Bean Jug public house on Friday night. Deceased came there about a quarter to twelve o'clock, and she asked for lodgings. The landlady said it was an untimely hour, and she could not have any. 
I offered her to go to my house and sleep with my children. I got home directly. She went to bed about halfpast twelve o'clock, and slept with my children. She said she came from Huddersfield. She said she wanted to find her uncle. She said they called her Waterhouse. She did not complain of being poorly. She looked well, and was respectably dressed. She had not anything to eat or drink before going to bed. I never saw her taste anything. She went to bed up stairs with my wife before me. I fell aleep directly. My wife called me up about half-past three o'clock, and she said the woman was dying. I got up and ran for a doctor. I got Mr. Marsden; she was dead when I got back in ten minutes. In her pockets were some medicine and pills, and the papers now produced-no letter or writing. She had nothing in the public house.

"Mary Sheard, wife of the last witness. It was near twelve o'clock on Friday night when my husband came home with the woman. (Confirms her husband as to conversation and going to bed.) The girl cried; she seemed distressed, and $I$ asked her the matter, and she said she was afraid she would have been obliged to stay out all night. She said she had come by the last train from Huddersfield. She said she had been trying to find her uncle, but could not. She said her mistress had given her leave to come. There was nothing in her manner or conduct which led me to think her mind affected. She was as right as I am this minute. She never was out of my sight from coming in to going to bed. I am sure she did not take anything before going to bed. She did not complain of pain. I was awake an hour before I went to sleep, and I am sure she did not get up, and I am sure she never did get up to take anything. About a quarter to two o'clock she awoke me, and was moaning. I got a light, and she cried out and moaned. I thought she was in a fit. I asked her if she had been so before. I was awoke by her moaning, not by her calling out, as if in great pain. She would not say where she had pain, but that she was poorly altogether. She was like as if in a fit-twitching. She threw her hands out and rolled; pain came on at intervals. Her legs were not rigid, but she had power over them, but could not turn herself when in pain. I gave her cold water. She did not complain of thirst. She sweated very bad. She had no difficulty in swallowing. She had no difficulty in speaking. She spoke as well as I did. When she threw her arms about she would not take anything. She died twenty minutes to four o'clock. An hour before she died she had no pain. She spoke of her father and mother, and told me her sweetheart had given her the bad disorder. She never said anything about her going to die, nor did I think she was. About an hour before she died, when she was easy, she said she had done something wrong; and then in about an hour she said, I told you some time since that I had done something wrong; I have taken poison; and she then became convulsed, and died in a minute or two. She was very much convulsed. There was no mug or glass or water in the room. She was neither sick nor purged after she came in. I am sure she did not get up after she went to bed. She was perfectly composed (sensible). In her pockets were found a bottle of medicine and a box of pills, and two empty papers of 'Battle's Vermin Killer', one marked poison."

Battle's vermin killer is sold in small packets, each packet consisting of an inner and outer paper envelope; it is of a blue colour, and appears to be composed of strychnine mixed with some farina, and coloured with Prussian blue; the quantity of strychnine being, so far as I can ascertain, about three grains to the whole packet.

When and how did she take the poison? This can only be a matter of inference. That she could take it before going to bed, appears hardly possible; nor for an hour after, if the statement of Mrs. Sheard is to be depended upon. In a quarter of an hour after this time, convulsions were 80 decided as to awaken the sleeping woman. There was no vessel or liquid (except the mixture) in the room, nor was thare any light. There was no spilling of the powder about the bod or room. The papers were quite dry, and, with the bottle, were in her dress pocket, which was lying on a chair near the bed. I am inclined to think she had, previously to learing Huddersfield, put the powder upon a very small portion of bread and butter, and eat it so soon as she found all quiet in the room; for it is in evidence that, about three months before, she had bought a packet of the powder, which was used by her in her master's house to destroy vermin. To put it upon bread and butter is, I am told, a common mode of mixing the poison, which is then readily eaten by rats and mice, the latter being not unfrequently found standing dead, stiff, and erect, near to the poison. (Indeed, I have since tried the effect of strychnine mixed with oatmeal, and have found many mice dead upon the plate containing it.) So that she was acquainted with the property of the powder, and probably thought that she, like the mice, would die quietly, without disturbing any one. If so taken, the quantity of bread and grease taken must have been small, as no distinct particles were seen in the stomach, which contained a small portion of greenish grey thick fluid, with a blue tinge.

I saw the body about twelve hours after death. The muscles were then flaccid, so that the want of rigidity mentioned was not owing to any post mortem change; besides, the weather was not very hot. The immediate cause of death was clcarly asphyxia, as all the appearances in the body showed. The softening of the medulla spinalis, which some experimenters have mentioned as being seen after death from strychnine, certainly was not found in this case; for I could not be sure that the slight softness mentioned as possibly existing at the lower part of the cervical portion really was noticeable or not.

A post mortem examination was made thirty hours after death. The body was well formed and plump, but very dirty, with considerable evidence of severe syphilitic diseasc. The left labium was greatly swollen, ulcerated, and indurated. The urine escaped through a large ulcer in the vagina, which communicated with the neck of the bladder.

Not more than the usual post mortem discoloration was present, except about the face and neck, which were livid and bloated. There was much foam about the mouth and nostrils. There was scarcely any rigidity-less than usual in the lower extremities; none whatever in the upper arms, chest, or body; little in the thighs, hand, and feet; the legs and lower arms being somewhat rigid. On removal of the integuments, the muscles seemed to be very flaccid.

CHest. The Lungs were emphysematous, from rupture of air-cells. The posterior part of the lower lobes was congested, and rather, but not excessively, œdematous ; otherwise they were quite healthy. The bronchial tubes were filled with frothy mucus, as were the larynx and upper part of trachea, the lining membrane of which was so congested as to be quite crimson in colour. The small muscles of the larynx and glottis were more firmly contracted than those of any other part of the body. There was no effusion into the pleuritic cavities or pericardium.

The Heart was perfectly flaccid, containing, on the right side, a large quantity of dark fluid blood, with some little soft pale fibrinous clots in the ventricle; on the left side, only some small quantity of dark soft coagulum. The structure of the heart was healthy.

AbBomen. The Stomach was distended with flatus, but containing not more than three ounces of a pale bluish grcen coloured thick gruelly fluid, without any appearance of other food. Near the larger end were some few spots of extrarasation in the mucous membrane, which, in other parts, was pale and natural in texture.

The Small Intestines, within and without, were pale, containing nothing except some bilious mucus and flatus.

The Large Intestines contained some small portion of excrementitious matter; but, like the small, they had in them little else than flatus.

The Spleen was large and dark from congestion.

The Liver and Kidneys were natural. 
The Bladiler was partly filled with natural urine, which escaped by au ulcer into the vagina.

The Uterus was enlarged, very dark, and congested, containing an ovum of about seren or eight weeks; ovaries very large, ind in one a large corpus luteus.

HEAD AND SPIN E. The vessels of the scalp; dura mater, and pis mater, were much distended with dark fluid blood. Bome serous effusion was present in muscles of the pia mater, upon the convolutions; none in the ventricles. The substance of both cerebrum and cerebellum was perfoctly natural, except, perhaps, having more vascular points on being sliced. The medulla oblongata was firm and natural. The spinal veins were congested; the medulla spinalis itself was natural, except perhaps (but of this I am doubtful) rather softer than usual at the bulbous expansion about the seventh cervical vertebra.

At the inquest, I suggested a chemical analysis of the contents of the stomach, which I had secured; but,jas there was an absence of any suspicion of the death having been occasioned by any one than herself, and : on the question being put to me, whether I could give a confident opinion as to strychnine being the cause of death, which I could the jury, to whom the question was left by the coroner, did not consider it necessary.

Subsequently, for my own satisfaction, with the kind assistance of my friend Mr. Morley, an analysis was made on Wednesday night, one hundred and fourteen hours after death, and eighty-four after examination, when strychnine was most decidedly detected by us in considerable quantity, by the method mentioned in toxicological works. The interior of the stomach was well washed with distilled water, which, being added to the contents taken from the stomach, and acidulated with sulphuris acid, was boiled for some little time, and filtered; then neutralised with lime, and again filtered, and evaporated to dryness: a portion of this residue, on being dissolved in spirit, gave, on the addition of a small quantity of nitric acid, the characteristic brown tint of strychnine.

So much was obtained in this manner, that a solution in spirit was left at our School of Medicine, to enable Dr. P. Smith, the lecturer on medical jurisprudence, to exhibit to the students from time to time the tests for strychnine from that actually obtained from the stomach of one poisoned by it.

I was not then aware that there existed any insurmountable difficulty in detecting strychnine within a short period after death, nor do I now understand the grounds upon which such an opinion rests, unless it be meant that, when the patient lives for some considerable period after the administration of the dose, the substance may be digested, and thus all traces be removed before death; but I much doubt whether such a dose, unless frequently repeated at intervals for some time, so as to keep up its action and a constant:igpasm, would prove fatal, unless by exhausting the nervous power, when symptoms would be different. If the dose be sufficient to cause death within four hours, I suspect it may commonly be found; and that it does not necessarily undergo decomposition for a considerable period after death, the present case furnishes conclusive evidence.

\section{BRONZED SKIN: DEATH: POST MORTEM EXA M I A T I N.}

By C. M. THOMPSON, Fsq., Westerham.

IN connexion with the subject of bronzed skin, mentioned by Dr. Budd, I will relate a case which occurred in my own practice, and may be interesting, because it was followed by a post mortem examination. It occurred many years ago; but, owing to its peculiar circumstances, is indelibly impressed upon my memory.

I was called to a woman "of colour", about thirty years of age. The skin over the whole body was dark bronze; the palms of the hands were white; the conjunctivæ were perfectly clear and white.
Having no doubt of her being a woman of colour, but a little puzzled by the shape of her features, I inquired from what country she came? At this question she seemed rastly amused: assured me she was a native of $\mathrm{my}$ own neighbourhood, and reminded me that $I$ had attended her on many occasions, some years before, while residing with an aunt in my town, at which time she was a fair and pretty girl. Having overcome my astonishment, I proceeded to examine her case. She stated that this discoloration had followed upon a fever, and had gradually increased. She was now suffering from severe dyspepsia, loss of appetite, frequent romiting, emaciation, and also from violent spasm, resembling gall-stone. There was no proof, however, of bilious obstruction; the eye was clear, the urine limpid, and the motions of a bright ochre colour.

I need not detail the treatment; nothing gave her relief; and after lingering for two months, she died from an unusually serere attack of spasms. The post mortem examination showed all the viscera in a healthy state; but the gall-bladder was greatly distended, and its duct entirely obliterated, while the hepatic duct was pervious.

I may here mention that I have, in the course of my practice, met with four cases of what is vulgarly called "black jaundice." In all these the bronze discoloration was very great; but there was a marked difference between these cases and the former ore, inasmuch as the orange eve and the obstructed bile clearly indicated the nature of the disease. In two of these I was enabled to make a post mortem examination, and in both I found the gall-ducts entirely obliterated; in one, from cancer of the pancreas; in the other, from simple occlusion of the common duct.

\section{THE METEOR.OLOGY OF 1855.}

\section{By J. A. HINGESTON, Esq., Brighton.}

CoMPARED with the fatal year of 1854, the weather of 1855 was both fine and healthy. The commencement of January was warm, the temperature being as much as $12^{\circ} \mathrm{Fahr}$. above the average; but it was followed by severe cold, which lasted from the 18th of January to the 21st of February. There was a good deal of snow and ice; and on the 18th of February, which was the coldest day of all, Fahrenheit's thermometer fell as low as $9^{\circ}$. The feathered tribes suffered sererely; the thrush family sought shelter in the public thoroughfares of towns and villages, and both land and water birds were driven instinctively to the more southern parts of England. Many shrubs and perennials were killed by the frost.

From March to November the weather was fine. The summer was mild and pleasant, and the autumn warm There were six months of continued fair weather, and the number of fine days throughout the year amounted to 196 . The mornings were particularly beautiful, and the starlight nights in the autumn most enchanting.

On comparing the climate of the Crimea with that of the south coast of England, a great similarity will be observed between the two countries. 'They are both upon the same isothermal line. (See K'aemtz's Meteorology, plate vi.) Troops encamped on the open downs near Brighton, far removed from their supplies, and harassed with the slow operations of a siege, would not have suffered less during the winter here than the allied armies did on the plateau between Sebastopol and Balaklava; and the hurricane that broke upon this coast on the 25th of October last would not have proved less disastrous than that which wrecked so many of our transports against the rocky coast of the Crimea on the 14th November, 1854-particularly so large a craft as the steamship Prince, heavily laden, with a lee-shore close astern, and nothing but a single stream anchor to hold her head against the fury of the storm.

From the 25th of March to the 5th of May, a drought prevailed, relieved only by a few light showers. In May, 1.50 inches of rain fell, but the drought returned, and continued till the 7 th of July. The grass was burnt up, or its 